\title{
Overcoming adverse stakeholder perception affecting tenement relinquishment
}

\author{
MKJ Finucane-Woodman Bioscope Environmental Consulting Pty Ltd, Australia \\ SJ Finucane Bioscope Environmental Consulting Pty Ltd, Australia
}

\begin{abstract}
Success in relinquishing a mine site and its associated tenure, and transferring the site to the next landholder, is strongly influenced by the perception held by regulators and other stakeholders of residual environmental, social and other risks. Even after comprehensive closure planning and stakeholder engagement, there is sometimes reluctance by the next landholder to finalise custodial transfer of the site and accept responsibility for any residual risk. This can occur even when residual risks are apparently well defined and understood, and are expected to be manageable in a way that will achieve agreed outcomes. This is because the way in which stakeholders perceive, respond to and/or act on risk is influenced by a wide range of factors including control, choice, novelty, propinquity and trust.

As a result of a study on current practices and future directions for mining tenure relinquishment in Western Australia conducted in 2017 and more recent research, four key sources of adverse stakeholder perception in relation to tenement relinquishment have been identified. Firstly, it was found that although there is extensive literature available to stakeholders on planning and implementing mine closure, there is little public guidance available on the relinquishment processes used in Western Australia. The absence of such information makes it difficult for stakeholders to independently validate information they are provided in relation to tenement relinquishment. Further, the lack of clearly defined procedures can create confusion about whether appropriate processes are being followed and therefore trigger concern about whether residual risks will be managed effectively. Overcoming this adverse perception requires development of better documented procedures for tenement relinquishment and socialisation of these procedures.

Secondly, the 2017 study and subsequent research found that responsibility for determining whether relinquishment can occur currently sits with key regulators and that while the views of other stakeholders are considered, they can be overridden. Consequently, stakeholders can feel that they have little choice in relation to, or control over, the outcome. Overcoming this adverse perception requires clearer definition of key stakeholders and provision of stronger mechanisms for incorporating these into decision-making regarding tenement relinquishment.

Thirdly, it was found that whether a stakeholder trusts (or distrusts) the data it has been provided in relation to residual risks and tenement relinquishment can strongly affect perception of the acceptability of these. Overcoming this adverse perception depends on the type of information provided, the methods used to collect the information and the way in which the information is communicated to stakeholders.

Finally, it was found that even when residual environmental, social and other risks are well defined, tenement relinquishment could still face final hurdles if the next land user has little or no appetite to take responsibility for those risks. In these cases, stakeholder perception of whether residual risks are acceptable is strongly influenced by that party's capacity to manage those risks effectively. Overcoming this perception can require significant capacity building in technical, financial and other disciplines.
\end{abstract}

Keywords: stakeholder perception, stakeholder engagement, mine site relinquishment, tenement relinquishment 


\section{Introduction}

Success in relinquishing a mine site and its associated tenure, and transferring the site to the next landholder, is strongly influenced by the way in which regulators and other stakeholders view residual environmental, social and other risks. However, even when residual risk has been minimised through careful and comprehensive closure planning and stakeholder engagement, there is sometimes reluctance by the next landholder to finalise custodial transfer of the site and accept responsibility for any residual risk. This can occur even when residual risks are apparently well defined and understood, and are expected to be manageable in a way that will achieve agreed outcomes. This is often due to differences in the way in which stakeholders initially perceive and respond to risk during planning and later when completion dates draw nearer.

People perceive, respond to, and act on risk in two fundamental ways: these are referred to as 'risk as feelings' (which relates to an individual's instinctive and intuitive reactions to danger) and 'risk as analysis' (where logic, reason and scientific deliberation are brought to bear) (Slovic \& Peters 2006). The way in which this perception and/or action manifests depends on the person's values, beliefs and experiences. Indeed, a wide range of factors affect stakeholder perception of risk. Ten key factors that affect how we assess risk have been identified by Slovic (2001), Ropeik (2002) and Anon. (n.d.) as:

- Dread. This can occur when we try to predict what will happen under certain circumstances. This prediction is often pessimistic and results in feelings of dread as terrible outcomes are imagined. When this occurs, we tend to perceive or assess the risk as being higher than it actually is.

- Control. Often, we perceive that we have more control than is actually the case. This 'control illusion' means that we often perceive risks as being less than they actually are. Conversely, if we that we have little control over a situation, we often perceive the risks to be higher than they actually are.

- Nature versus man-made. Natural disasters are often seen as less risky than those created by humans, possibly because we feel that we have more control over human events than natural ones.

- Choice. If someone has a choice between two equally risky actions or items, they often perceive that the risk resulting from making that choice is lower than it actually is simply because having a choice tends to propagate a sense of control.

- Children. Whether children are involved in a situation tends to make risks seem higher than if a situation only affects adults.

- Novelty. When we encounter a risk that we have not come across previously, we often consider these to be more perilous than a risk with which we are familiar. This may because we allow an additional Factor of Safety for unknown risks.

- Publicity. A risk is more likely to be perceived as being more significant than it actually is if it has received a lot of public attention.

- Propinquity. This is defined as the state of being close to someone or something. This sense of nearness or proximity to a risk means that a risk is likely to be perceived as higher than it really is.

- Risk-benefit trade-off. A risk may be perceived to be less significant than it actually is if there is opportunity for both benefits and hazards.

- Trust. When a risk involves the actions of others, the way in which we assess the risk depends on the extent to which we trust the other party or parties involved in the action.

Four key sources of adverse stakeholder perception in relation to mine relinquishment were identified as a result of targeted literature review and interviews with selected government representatives and industry personnel working in the Western Australian (WA) mining industry conducted in 2017 (Finucane-Woodman 2017) and additional research conducted by the authors of this paper subsequent to completion of that 
study. These sources and the challenges that they present in relation to tenement relinquishment are discussed below, and potential solutions are proposed.

\section{Defining and documenting tenement relinquishment processes}

It is widely recognised that good regulation of the mining industry includes ensuring adequate management of environmental, social and other risks posed by end-of-mining outcomes (Auditor General 2011). In WA, stronger requirements for mine closure and rehabilitation planning have been introduced over several decades to reduce the risk of poor environmental and other outcomes following cessation of mining and tenement relinquishment (Auditor General 2011). These are outlined in Table 1 and discussed below.

Table 1 Timeline for development of selected minerals industry initiatives and regulatory guidance on mine closure and relinquishment in Western Australia (Finucane-Woodman 2017)

\begin{tabular}{|c|c|c|}
\hline Era & Year & Milestone \\
\hline \multirow[t]{2}{*}{ 1970s } & 1972 & Environmental Protection Act 1971 introduced \\
\hline & 1978 & Mining Act 1978 introduced \\
\hline \multirow[t]{2}{*}{ 1980s } & 1980 & $\begin{array}{l}\text { Guidelines for Waste Dump Design and Rehabilitation produced by the } \\
\text { Western Australian Department of Mines }\end{array}$ \\
\hline & 1986 & $\begin{array}{l}\text { Environmental Protection Act } 1986 \text { replaces the Environmental Protection Act } \\
1971\end{array}$ \\
\hline \multirow[t]{11}{*}{ 1990s } & 1990 & $\begin{array}{l}\text { Australian Mining Industry Council (AMIC) issues a Mine Rehabilitation } \\
\text { Handbook, which was prepared in cooperation with, and endorsed by, the } \\
\text { Mines Departments and Chambers of Mines in all states of Australia }\end{array}$ \\
\hline & 1994 & $\begin{array}{l}\text { Environmental Management of Quarries: Development, Operation and } \\
\text { Rehabilitation Guidelines published by the Department of Minerals and Energy } \\
\text { (DME) }\end{array}$ \\
\hline & 1995 & $\begin{array}{l}\text { Commonwealth Government issues the Best Practice Environmental } \\
\text { Management in Mining module on rehabilitation and revegetation }\end{array}$ \\
\hline & 1996 & $\begin{array}{l}\text { DME issues Guidelines for Mining in Arid Environments that address land } \\
\text { rehabilitation techniques, rehabilitation monitoring and completion criteria }\end{array}$ \\
\hline & 1997 & Land Administration Act 1997 introduced \\
\hline & & $\begin{array}{l}\text { Department of Industry and Resources (DoIR) issues a guideline on Safety Bund } \\
\text { Walls Around Abandoned Open Pit Mines }\end{array}$ \\
\hline & & $\begin{array}{l}\text { DME issues Guidelines for Mining Project Environmental Approval in Western } \\
\text { Australia }\end{array}$ \\
\hline & 1998 & $\begin{array}{l}\text { DME publishes Guidelines to Help You Get Environmental Approvals for Mining } \\
\text { Projects in Western Australia }\end{array}$ \\
\hline & & $\begin{array}{l}\text { Minerals Council of Australia (MCA) (formerly AMIC) issues a revised Mine } \\
\text { Rehabilitation Handbook }\end{array}$ \\
\hline & & $\begin{array}{l}\text { Commonwealth Government issues the Best Practice Environmental } \\
\text { Management in Mining module on landform design for rehabilitation }\end{array}$ \\
\hline & 1999 & MCA issues its Mine Closure Policy \\
\hline
\end{tabular}




\begin{tabular}{|c|c|c|}
\hline Era & Year & Milestone \\
\hline \multirow[t]{13}{*}{$2000 \mathrm{~s}$} & \multirow[t]{3}{*}{2000} & $\begin{array}{l}\text { Strategic Framework for Mine Closure published by Australian and New } \\
\text { Zealand Minerals and Energy Council (ANZMEC) and MCA }\end{array}$ \\
\hline & & $\begin{array}{l}\text { MCA launches the Australian Minerals Industry Code for Environmental } \\
\text { Management }\end{array}$ \\
\hline & & $\begin{array}{l}\text { Western Australian Chamber of Minerals and Energy issues Mine Closure } \\
\text { Guidelines for Mineral Operations }\end{array}$ \\
\hline & 2001 & $\begin{array}{l}\text { DME publishes a report entitled Draft Criteria for Mine Closure within the } \\
\text { Context of the DME }\end{array}$ \\
\hline & 2002 & $\begin{array}{l}\text { Commonwealth Government issues the Best Practice Environmental } \\
\text { Management in Mining module on mine decommissioning }\end{array}$ \\
\hline & 2003 & Contaminated Sites Act 2003 introduced \\
\hline & 2004 & BHP Billiton issues its first Closure Standard \\
\hline & \multirow[t]{3}{*}{2006} & $\begin{array}{l}\text { Handbooks on Leading Practice Sustainable Development Program for the } \\
\text { Mining Industry are published by the Commonwealth Government (including } \\
\text { handbooks on Mine Closure and Completion, and Mine Rehabilitation) to } \\
\text { replace the } 2002 \text { Best Practice modules }\end{array}$ \\
\hline & & Guidelines for Mining Proposals in Western Australia issued by the DoIR \\
\hline & & $\begin{array}{l}\text { Environmental Protection Authority (EPA) issues Guidance Statement No 6: } \\
\text { Rehabilitation of Terrestrial Ecosystems }\end{array}$ \\
\hline & 2007 & $\begin{array}{l}\text { Department of Mines and Petroleum (DMP) issues guidelines on Mineral } \\
\text { Exploration/Rehabilitation Activities }\end{array}$ \\
\hline & \multirow[t]{2}{*}{2008} & $\begin{array}{l}\text { International Council of Mining and Metals publishes its Toolkit for Planning for } \\
\text { Integrated Mine Closure }\end{array}$ \\
\hline & & Anglo American launches its Mine Closure Toolbox \\
\hline \multirow[t]{8}{*}{$2010 s$} & 2010 & $\begin{array}{l}\text { Strategic Framework for Managing Abandoned Mines in the Minerals Industry } \\
\text { issued by the Ministerial Council on Mineral and Petroleum Resources and } \\
\text { MCA (developed with input from the DMP) }\end{array}$ \\
\hline & 2011 & Guidelines for Preparing Mine Closure Plans issued by the DMP/EPA \\
\hline & \multirow[t]{2}{*}{2012} & Mining Rehabilitation Fund Act 2012 introduced \\
\hline & & MCA launches its Land Stewardship Policy \\
\hline & 2013 & Mining Rehabilitation Fund Regulations 2013 issued \\
\hline & \multirow[t]{2}{*}{2015} & Updated Guidelines for Preparing Mine Closure Plans issued by the DMP/EPA \\
\hline & & $\begin{array}{l}\text { EPA issues Environmental Protection Bulletin No. } 19 \text { to clarify its involvement in } \\
\text { mine closure }\end{array}$ \\
\hline & 2016 & $\begin{array}{l}\text { Updated Guidelines for Mining Proposals in Western Australia issued by the } \\
\text { DMP }\end{array}$ \\
\hline
\end{tabular}

During the 1980s and 1990s, it was common for rehabilitation to be discussed in a mine's environmental impact assessment and permitting applications, but usually only in general terms. This was in line with standard industry practice of the day with the mining environmental assessment guidelines produced by the then DME in 1998 only requiring an outline of rehabilitation procedures and a commitment to perform progressive and final rehabilitation (Department of Minerals and Energy Western Australia 1998). It was 
only when these guidelines were updated in 2006 that they included a requirement for mining companies to prepare a Mine Closure Plan based on site-specific completion criteria (Department of Industry and Resources 2006).

When the Commonwealth Government's EPA launched the Best Practice Environmental Management in Mining modules in the mid-1990s, some of the first modules to be published focused on rehabilitation and revegetation (Ward 1995) and landform design for rehabilitation (Lindbeck \& Hannan 1998). Towards the end of that decade, the MCA published the updated Mine Rehabilitation Handbook (MCA 1998) and produced its first Mine Closure Policy a year later.

Mine closure planning continued to gain momentum in the late 1990s and 2000s, and additional mine closure guidelines were produced at a state and national level. These included the Mine Closure Guideline for Mineral Operations in Western Australia (Chamber of Minerals and Energy of Western Australia 1999), the 2000 Australian Minerals Industry Code for Environmental Management, and the Strategic Framework for Mine Closure (ANZMEC/MCA 2000). Shortly thereafter, a document entitled Draft Criteria for Mine Closure within the Context of the Department of Minerals and Energy of Western Australia was produced (DME 2001) and the Australian Commonwealth Government produced its first mine decommissioning guideline (Lacy \& Koontz 2002). Around this time, it became common practice to include a conceptual closure plan in the environmental impact assessment documents and for the finalisation of the plan to occur earlier in the project life, rather than leaving this to the end of mine life.

As preparation of conceptual closure plans as part of mining environmental approvals processes became standard practice in WA, the mining industry sought guidance in relation to government expectations on mine rehabilitation and closure. As a result, the WA EPA produced its first guidance statement on rehabilitation of terrestrial ecosystems (EPA 2006). Industry organisations and individual companies also continued to develop and publish policies and guidelines in this discipline with the International Council of Mining and Metals (ICMM) launching an Integrated Mine Closure Planning Toolkit (ICMM 2008) and Anglo American launching its Mine Closure Toolbox (Anglo American 2013).

In June 2011, in recognition of the importance of integrated mine closure planning, the DMP and the EPA published the first WA Guidelines for Preparing Mine Closure Plans (DMP \& EPA 2011). The guidelines aimed to ensure that each of the active mine sites in this state had a process in place for its closure, decommissioning and rehabilitation. The guidelines were updated in 2015 (DMP \& EPA 2015), but still contain little information on the state's expectations and requirements for tenement relinquishment. This leads to uncertainty for proponents, regulators and other stakeholders, which in turn can increase stakeholder perception of tenement relinquishment risks.

The links between relinquishment and closure planning are undeniable but, as can be seen above, there is significantly more literature available on closure than on relinquishment. It is apparent that the subject of mine closure planning is well documented, but the processes for relinquishment are still at an early stage of documentation and implementation (Lacy \& Bennett 2016). There is also a need for unified language. Different agencies and departments using various terms synonymous with relinquishment such as 'resumption', 'reclamation' and 'surrender of tenements' can make searching for information on the relinquishment process difficult and near inaccessible to the layman. In particular, there is no clearly defined model for tenement relinquishment in WA and there is little or no information on any dependencies between requirements or the sequence in which the steps to be taken for relinquishment need to occur (Finucane-Woodman 2017). The absence of such information and the inaccessibility of the language used make it difficult for stakeholders to independently validate information they are provided in relation to tenement relinquishment. Further, the lack of clearly defined procedures can create confusion about whether appropriate processes are being followed and therefore trigger stakeholder concern about whether residual risks will be managed effectively.

In the absence of clear regulatory instruments, companies, governments and mine-affected communities often enter into ad hoc processes of negotiation as a means of forming agreement over complex social, environmental and economic liabilities (Owen \& Kemp 2018). Consequently, there is a need for a single 
documented process as well as guidelines to oversee the relinquishment of mining tenure in WA (De Sousa 2015). In particular, well-defined policies and procedures are important as they provide a transparent road map for tenement relinquishment, ensure compliance with legislation and regulations, guide decisionmaking and streamline internal and external processes.

\section{$3 \quad$ Involving stakeholders in decision-making}

Based on information reviewed by Finucane-Woodman (2017), it appears that responsibility for most of the actions required for tenement relinquishment in WA rests with the proponent, with little information readily available on the roles and responsibilities of regulators and other stakeholders. This leads to uncertainty for proponents, regulators and other stakeholders in relation to what is expected and required of them, and can result in lengthy delays in tenement relinquishment.

\subsection{Who are your relinquishment stakeholders?}

While it is usually not difficult to identify regulators and other government stakeholders relevant to relinquishment of a mine, it can sometimes be difficult to determine who forms the 'community' relevant to the mine. In mining industry terms, a community is generally defined as the inhabitants of the immediate and surrounding areas who are affected by a company's activities (Wang et al. 2016), but in practice it can sometimes be difficult to define the zone of influence. Further, this can change as the mining company approaches and then enters the closure and relinquishment phases. This can be exacerbated by the fact that it is not always easy to predict how communities will be affected by mine relinquishment, particularly for those sites with a long mine life.

When mining companies look for a collective response from a community in relation to plans for relinquishment, or attempt to gauge community acceptance or resistance to custodial transfer of a former mine, they often aim to engage with 'key stakeholders' and 'community representatives' as if the views of these individuals are representative of the wider community. While this approach has merit, it means that companies sometimes overlook the fact that a community's response is shaped by the choices and strategic interactions of individuals within the community, by private rather than public responses, and individual rather than collective actions (Wang et al. 2016). On this basis, it is important that the company develops a sound understanding of the range of stakeholders interested in and/or affected by a relinquishment project and the roles played by these stakeholders (including whether they are decision-makers, influencers, observers etc.).

\subsection{What is meant by consultation?}

It is common for regulators to require that completion criteria be developed in consultation with key stakeholders (see, for example, DMP \& EPA 2015). One of the key factors responsible for the success of the Mt Kembla project was community involvement from early project scoping and throughout development of the overall site master plan (Larance 2012). However, it may not be possible to identify the next landholder and other stakeholders until late in the life of a mine. Although mining companies aim for early identification of the post-mining custodian and identification and agreement on realistic closure and relinquishment objectives with all relevant stakeholders, this is not always possible. In cases such as this, it is suggested that proponents consult with the Department of Planning, Lands and Heritage (or local equivalent) to establish an alternate or baseline set of closure/relinquishment objectives.

However, relinquishment of a closed mine can become complicated if there is disparity between the expectations and the next landowner or land user (Butler \& Bentel 2011). Further complications can arise if different stakeholder groups hold different views to each other on what constitutes closure success and what conditions should exist to allow tenement relinquishment. Conflicting stakeholder views on what constitutes an appropriate end point for mine closure can adversely affect the relinquishment process. 


\subsection{Who makes the final decision?}

Given the above, who has the final say in defining the 'end point' for mine sites? In WA, this responsibility sits with the regulators, with the 2015 Guidelines for Preparing Mine Closure Plans (DMP \& EPA 2015) stating that:

"Once established and agreed to by the regulators, the completion criteria (and associated performance indicators) will form the basis on which mine closure performance is measured and reported to Government (and the community where applicable)."

Further, in her presentation of the Department of Mines, Industry, Regulation and Safety's review of the relinquishment process in WA to the 2018 Goldfields Environmental Management Group conference, Copeland (2018) stated that relinquishment is defined as:

"Acknowledgement from all relevant government agencies that closure obligations have been met. The proponent is released from all forms of mining related security and management for the land has been returned to the post mining land manager(s)."

Based on the above, it is clear that tenement relinquishment in WA cannot occur without regulator acknowledgement that closure obligations have been met. However, the Copeland (2018) definition suggests that relinquishment is something to be negotiated between government departments and the proponent, and it could be construed that the next landholder (if not a government department) could be reliant on the proponent and/or regulators to adequately represent its interests in deciding on an appropriate end point.

Even though the 2015 Guidelines require that completion criteria be developed in consultation with key stakeholders, the fact that 'relevant government agencies' are the only decision-makers identified in the above definition of relinquishment and that there is no explicit inclusion of the next landholder or other stakeholders in this means that their concerns may have little influence or simply be ignored during this decision-making process. Consequently, stakeholders can feel that they have little choice in relation to, or control over, the outcome. Smith (2012), referring to the degree of angst expressed by Aboriginal landowners in the Northern Territory, states that "their concerns will continue to be ignored when the time comes for closure of operating mines...".

Overcoming this adverse perception requires clearer definition of key stakeholders, their roles, and provision of stronger mechanisms for incorporating them into decision-making regarding tenement relinquishment and post-closure management of the former mine site.

\section{$4 \quad$ Building trust through credible communication of risk}

\subsection{Transparency}

In participating in closure and relinquishment, it important that stakeholders trust the information with which they are presented. For example, a survey of three culturally distinct groups of Aboriginal landowners affected by large mining projects in the Northern Territory found that there was a high degree of distrust of mining companies and regulators due, at least in part, to poor communication and consultation on environmental matters (Smith 2012). In contrast, Larance (2012) found that honest and transparent two-way dialogue between the project development team and the community improved the outcomes, acceptance, approvals and delivery of the Mt Kembla Mine Memorial Pathway. Transparent disclosure was also considered to be key to the success of closing the Beenup mineral sands mine (Butler \& Bentel 2011).

Lack of transparency and high levels of uncertainty regarding ongoing constraints on post-mining land use have been particularly highlighted by the 'Collingwood Park case' where the site of a historical underground colliery in Ipswich, Queensland, was mistakenly converted to low density residential development that subsequently experienced subsidence. In this case, the state was aware of subsidence issues associated 
with irregular underground pillars as the proponent (Westfalen) had provided the state with accurate mine plans and regular mine inspections had been conducted by state officials, but this information was not provided to the local government council. Consequently, when the local government council proposed to rezone the land for residential redevelopment following cessation of mining, it did not have details about the design of underground pillars relevant to subsidence. The land was later developed for residential purposes and was subject to major subsidence (Bowie \& Fulcher 2017).

The State of Queensland established a compensation scheme for residents within the subsidence area, but residents with properties located close to, but outside of, the subsidence area instituted proceedings in the Queensland Supreme Court. The case, Butler v The State of Queensland, was heard in 2013 and resulted in the court additionally requiring the state to compensate residents immediately adjacent to the subsidence (Bowie \& Fulcher 2017). Although the state contended that the residents could have taken steps to protect themselves by making enquiries, conducting searches and commissioning their own geotechnical assessments, it was noted by the court that there was no reasonable way that the residents could have obtained information on the 'crucial matters' known to the state about the underground pillar design (Bowie \& Fulcher 2017). In addition, the court held that the local government also had no way of knowing about the risk of subsidence, stating that:

"Local government entities make assessments as to the risk of subsidence to future buildings on that land based on the conditions imposed on any mining grant, having been properly supervised sand enforced during mining operation. Local government entities have no way of ascertaining whether there has been compliance with the conditions, other than an acceptance the defendant [i.e. the State] will have complied with its statutory obligations." (Bowie \& Fulcher 2017)

The court concluded that the state had a duty of care to vulnerable future landowners and that this was not limited to the land that had subsided, but that the foreseeable risk of economic loss had extended to nearby residents providing that the damage claimed was not too remote (Bowie \& Fulcher 2017). Consequently, the state's compensation scheme was extended to include residents immediately adjacent to the subsidence (Bowie \& Fulcher 2017).

\subsection{Credibility}

Stakeholder-related risk is one of the major non-technical risks responsible for delays to mining projects (Franks et al. 2014), so it comes as no surprise that stakeholder engagement is seen as the best way to mitigate these risks and achieve sustainable outcomes (Wang et al. 2016). Beecher et al. (2005) note that what may matter most in risk communication is the credibility of the person providing the information and the level of trustworthiness, fairness and respect that the person (or organisation) demonstrates. Indeed, in communicating about relinquishment, who communicates the issues and how they do so can strongly influence the outcome of the engagement process (Beecher et al. 2005). However, the provision of credible, legitimate and salient data and other information is also critical to success of engagement processes (Beecher et al. 2005).

Credibility of data is derived from the scientific adequacy of technical evidence and argument (Cash et al. 2003). However, legitimacy of data depends on the way in which scientific processes are conducted. It depends on whether rigorous data have been obtained with adequate quality assurance; reliable methods that are acceptable to peers and are reproducible have been utilised; analysis techniques that yield reasonable findings rationally explained from the data have been applied; conclusions are defensible and reasonable; and the limitations associated with the research have been acknowledged clearly (Beecher et al. 2005). Finally, to be salient, scientific research and studies need to be relevant to a variety of stakeholders including decision-makers, must answer meaningful questions in a way that can be put to use and be understood by various stakeholders, and must inform, shape and frame decision-making (Beecher et al. 2005; Cash et al. 2003). 


\subsection{Processing of information by stakeholders}

Interestingly, Beecher et al. (2005) found that there are measurable differences in how technical specialists and community stakeholders define and assess risk. Understanding how stakeholders obtain and process information is as important in engaging about relinquishment as it is in engaging about other aspects of the mining process.

In general, people use both analytic and experiential methods to process information and use these to different extents, depending on the situation. An analytic system tends to be deliberative and reason oriented, often considers all available information and requires evidence-based justification. It looks for logical connections and typically takes time. In comparison, an experiential system tends to be rapid and intuitive. It is typically holistic and affective, with behaviour and responses strongly influenced by past experiences (Denes-Raj \& Epstein 1994).

"People often interpret the same information very differently. As psychologists, we are more than familiar with the finding that our brains selectively attend to, process and recall information. One consequence of this is 'confirmation bias,' a strong tendency to automatically favor information that supports our prior expectations." (van der Linden \& Lewandowsky 2015)

The suggested action to remedy this is to present information to stakeholders in a format that is easy to understand but not so simple as to be insulting or be construed as hiding facts, and do so in a setting that puts the stakeholders at ease but still able to focus.

Engage early and continue to engage frequently. Take them on the journey and be transparent so that there are no surprises. These suggestions are to build a rapport and sense of reliability with the stakeholders. But be careful to avoid stakeholder fatigue - create a task group to oversee the relinquishment transition and liability reduction works made up of stakeholders, government department officials and independent experts. This method of reporting to a unified body of government officials was implemented in the WA case of the Jarrahdale site (Finucane-Woodman 2017). Alcoa (the proponent) was required to make regular contact with the group as well as submitting updated plans for operations as they were available which aided in maintaining clear and consistent closure and relinquishment goals. Jarrahdale was fortunate in that the site had a clear line of succession for land use returning to state ownership, so independent experts and key stakeholders were already represented in the group.

Rather than just consulting, involve stakeholders in the planning and implementation of relinquishment activities. Sharing control of the process and collaborating with a diverse range of stakeholders allows the process to be more focused and relevant to these parties, and better and more widely understood. While processes such consensus building, collaborative research and joint fact finding usually take more time, effort and budget than traditional research processes, they can also be useful in ensuring that study outcomes are more credible to the broader public, and can help to avoid the delays and costs that can accrue when conflict erupts over science-intensive decisions (Beecher et al. 2005).

In addition to understanding how stakeholders process information, it is important to understand how long that processing can take. There is a need to ensure timely engagement and information transfer while avoiding engagement fatigue and information overload. Information overload is defined by Mulder et al. (2006) as simply receiving too much information and is related to:

"...the complexity and pace of today's knowledge-intensive society, the technology to deal with this complexity, and the fact that new technology increases as well as reduces information overload. There is too much information to handle and too little time to 'process' and 'digest' the information."

If the process of engaging about relinquishment and providing information is left to the closure stages of the life of the mine site, this effect is compounded by more new information at a late stage with immediate need to deliver decisions. 
Regulators and/or other stakeholders may be reluctant to allow tenement relinquishment even when a company has met all of its rehabilitation and closure obligations as liability for any residual, unforeseen or latent impacts then reverts to government and could have impacts on a local or possibly regional scale (Finucane \& Bastow 2016). For example, issuance of a mine closure certificate for De Beers' The Oaks diamond mine was delayed despite the fact that all rehabilitation targets had been met and the agreed post-closure land use had been attained because there was a need for final resolution of ongoing liabilities and certainty regarding future land use (Botham et al. 2013).

\subsection{Engagement success factors}

Relinquishment of a closed mine is likely to be influenced by community concern for the site and the regulator's or land holders' experience of, and appetite for, risk. As discussed above, stakeholder perception of residual closure risk is greatly affected by the legacies of mines where rehabilitation has failed (or is seen to have failed) (Smith 2012), where closure defects were not apparent or not recognised at the time of custodial transfer (Butler \& Bentel 2011), or where these were known and not disclosed (Bowie \& Fulcher 2017). With minimal cases of successful relinquishment and a growing awareness of the environmental risks associated with abandoned mines (De Sousa 2015), it is useful to publish or otherwise distribute information on where successful relinquishment has occurred and to elucidate success factors and constraints. Three case studies are discussed below.

\subsection{Case studies}

There have been a number of cases of successful relinquishment in WA. These include the Bottle Creek gold project, the Jarrahdale aluminium and bauxite project and the Yoganup Extended mineral sands project.

\subsubsection{Bottle Creek}

The Bottle Creek gold project site is located $95 \mathrm{~km}$ north-west of Menzies in the Goldfields and was operational from 1988 to 1989. Comprising three open pits, a plant, two Tailings Storage Facilities, Waste Rock Landforms and a run-of-mine pad, the project ceased operations due to an unexpectedly small resource deposit and went into unplanned closure. During rehabilitation works for this site, a cyclonic event caused much damage to the site and the proponents were declined final relinquishment sign-off twice due to the need for more rehabilitation works as standards were updated and targets revised (Finucane-Woodman 2017). The site was successfully relinquished in 2001.

\subsubsection{Jarrahdale}

The Jarrahdale bauxite project site was one of three such mines in the Darling Range and operated from 1963 to 1999 while the Willowdale and Huntly mines are still in operation. Drawing its name from the nearby town of Jarrahdale, which in turn in located inside a Jarrah forest. The three sites comprise shallow pit mining of approximately 550 ha per year and progressive closure rehabilitation activities were undertaken as each deposit was exhausted (Finucane-Woodman 2017). Updated plans and progress reports were submitted regularly to a multi governmental agency group, as detailed in Section 4.3. The Jarrahdale site was relinquished in 2005.

\subsubsection{Yoganup Extended}

The Yoganup Extended heavy mineral sands project site was made of three sites (Yoganup, Yoganup West and Cloverdale) all contained on privately owned Freehold land and operated from 1998 to 2008. Each of these sites comprised of open pits, stockpiles and a processing facility. With the site reverting back to private property post-closure, the key stakeholders were presented with options for rehabilitation and elected to have the land returned to its pre-mine state (Finucane-Woodman 2017). The project sites were relinquished in 2013. 


\subsubsection{Analysis}

Bottle Creek is an example of a site being returned to unallocated Crown land. With no other land manager involved, this land would return to management of the Department of Lands. As such, with no other required land use post-mining, the closure objectives were focused on environmental outcomes. These types of technical objectives take time to show true outcomes and are not always controllable by a proponent. However, in this case it was the environmental outcomes that the key stakeholder (the Department of Lands) required and being the first example of successful, voluntary relinquishment in WA, the government were motivated by the site's future use as a case study of success (Elliot, pers. comm., October 2017).

Jarrahdale and Yoganup Extended both identified land managers (key stakeholders) who would take over after relinquishment. It is possible that the presence and involvement of these parties allowed for a more streamlined closure process as well as the ability to focus on outcomes-based closure objectives with consultation and negotiation from stakeholders. Both also had economic drivers stemming from their post-mining land uses, which may have also eased concerns over liability and helped both the proponent and the future land manager to more readily agree on objectives before relinquishment and handover (Finucane-Woodman 2017).

\section{$5 \quad$ Final hurdles}

Even when residual environmental, social and other risks are well defined, tenement relinquishment can still be adversely affected if the next landholder or land user has little or no appetite or capacity to accept custodial transfer of residual risk. This can be because that party feels ill-equipped to manage those risks effectively. Overcoming this issue could require capacity building initiatives for the next landholder in technical, financial and other disciplines.

Different stakeholders may require different types of support and lead times in order to develop the capacity and capabilities to take responsibility for a relinquished mine site and any residual risks. For example, if the pre-mining land use of a mine site was pastoral, and the site will be transferred to a pastoralist following site closure, then it is reasonable to expect that this land user will already be capable of managing most, if not all of the residual risks and that it should be relatively straightforward to put management plans and funding into place to manage any other remaining issues (depending on the site's risk profile). However, additional effort is likely to be required for some of the other stakeholder groups. For example, Solomon et al. (2008) suggests that when the mining industry has ceased to operate in the Pilbara region of WA, it is the Aboriginal people who will remain and who would seem to be strategically placed to manage mines that have been relinquished. However, Smith (2012) states that post-closure problems associated with mines are usually beyond their capacity to cope. Consequently, to be successful, Aboriginal landowners will need to be provided with the necessary tools, equipment and funding (Smith 2012).

An additional measure to ensure transfer to the next landholder is to ensure that there is sufficient funding available to be used for future management of the residual risk posed by the closed mine site. Mackenzie (2016) suggests that the use of self-perpetuating funding initiatives that run independently of regulator control can be used to assure stakeholders (proponents and regulators included) that the costs of closure are secured in advance.

\section{"Self-perpetuating funds can provide financial surety in the event of foreseen or unforeseen closure risks, provide for organisation and management of a custodial body, provide an ongoing benefit to the community or the environment, and can fund ongoing security and maintenance for a closed mine." (Mackenzie 2016)}

The initial funds are stored in high interest accounts with the interest re-invested until closure activities take place, at which point the interest is used to fund monitoring and maintenance of closure objectives with the initial funds still available to be used in the case of unplanned closure or as additional funds to 
achieve closure outcomes. This is intended to ease the worries of future land holders and regulators and help streamline the relinquishment and future management processes.

\section{Conclusion}

At the 2011 Mine Closure conference, Butler \& Bentel (2011) remarked that they had been unable to find a single authoritative reference that could provide a comprehensive relinquishment process or define the components of a relinquishment plan. This is still the case for WA, although steps are being taken by the Department of Mines, Industry Regulation and Safety to address this.

This and many other concerns inspire dread in stakeholders at the prospect of relinquishment of mining tenure they are associated with. The perception that the residual risk posed by the site is too great in the minds of the regulators for the proponent to be allowed to divest their responsibilities; that relinquishment cannot be achieved due to the lack of clear processes and information; that the costs of closure, maintenance and monitoring will not be appropriately paid for or conducted before transfer of the tenement are but a few.

The importance of stakeholder involvement in deciding on outcomes-based relinquishment goals and has been shown in previous cases of successful relinquishment in WA. This is best achieved by early and continual engagement with relevant stakeholders to decide on the relinquishment objectives and the methods used to achieve them.

\section{Acknowledgement}

Some of the information provided in this paper was collected during an internship completed during the final year of a bachelor's degree at Murdoch University. The internship was supervised by Dr Jane Hutchison from Murdoch University and Shannon McKenzie of Mine Earth. Their input to this study is acknowledged and appreciated. The authors also thank Kate Tarnowy of Bioscope Environmental for reviewing a draft of this paper and providing technical advice.

\section{References}

Anglo American 2013, Mine Closure Toolbox, Johannesburg.

Anon., n.d., Ten Risk-perception Factors, Changing Minds, viewed 24 July 2019, http://changingminds.org/explanations/ meaning/ten_risk-perception_factors.htm

Australian and New Zealand Minerals and Energy Council \& Minerals Council of Australia 2000, Strategic Framework for Mine Closure.

Auditor General 2011, Ensuring Compliance with Conditions on Mining, Auditor General of Western Australia, Perth.

Beecher, N, Harrison, E, Goldstein, N, McDaniel, M, Field, P \& Susskind, L 2005, 'Risk perception, risk communication and stakeholder involvement for biosolids management and research', Journal of Environmental Quality, vol. 34, no. 1, pp. 122-128.

Botham, N, Bower, G, Vercoe, J \& Lerotholi, N 2013, 'Mine closure liabilities and risk management - minimising the pitfalls in decommissioning policy', The Southern African Institute of Mining and Metallurgy Mining Environment and Society Conference, The Southern African Institute of Mining and Metallurgy, Johannesburg.

Bowie, L \& Fulcher, J 2017, 'Planning for post-mining land uses', paper presented at the Planning Institute of Australia (Qld) Annual Conference, Bundaberg, 14 September 2017.

Butler, H \& Bentel, GM 2011, 'Mine relinquishment - processes and learnings', in AB Fourie, M Tibbett \& A Beersing (eds), Proceedings of the 6th International Conference on Mine Closure, Australian Centre for Geomechanics, Perth, pp. 3-12.

Cash, DW, Clark, WC, Alcock, F, Dickson, NM, Eckley, N, Guston, DH, Jager, J \& Mitchell, RB 2003, 'Knowledge systems for sustainable development', Proceedings of the National Academy of Sciences of the United States of America, vol. 100, iss. 14 , pp. 8086-8091.

Chamber of Minerals and Energy of Western Australia 1999, Mine Closure Guideline for Minerals Operations in Western Australia, Perth.

Copeland, L 2018, 'Developing a whole of government approach to mine site relinquishment in WA', Proceedings of the 2018 Environmental Management Workshop, Goldfields Environmental Management Group, Kalgoorlie, pp. 729-740.

Department of Industry and Resources 2006, Guidelines for Mining Proposals in Western Australia, Perth.

Department of Minerals and Energy Western Australia 1998, Guidelines to Help You Get Environmental Approval for Mining Projects in Western Australia, Perth. 
Department of Minerals and Energy of Western Australia 2001, Draft Criteria for Mine Closure within the Context of the Department of Minerals and Energy of Western Australia, Perth.

Department of Minerals and Petroleum \& Environmental Protection Authority 2011, Guidelines for Preparing Mine Closure Plans.

Department of Minerals and Petroleum/Environmental Protection Authority 2015, Guidelines for Preparing Mine Closure Plans.

Denes-Raj, V \& Epstein, S 1994, 'Conflict between intuitive and rational processing: when people behave against their better judgement', Journal of Personality and Social Psychology, vol. 66, no. 5, pp 819-829.

De Sousa, K 2015, Do you know how to relinquish a mine site in Western Australia? Part 1, Astron, East Perth, viewed 24 July 2019 , http://www.astron.com.au/news/do-you-know-how-to-relinquish-a-mine-site-in-weste/

Environmental Protection Authority 2006, Guidance for the Assessment of Environmental Factors: Rehabilitation of Terrestrial Ecosystems, Perth.

Finucane, SJ \& Bastow, B 2016, 'When is it time to say enough is enough for historical mine rehabilitation and closure? A Pilbara case study', in AB Fourie \& M Tibbett (eds), Proceedings of the 11th International Conference on Mine Closure, Australian Centre for Geomechanics, Perth, pp. 369-380.

Finucane-Woodman, M 2017, Mining Tenure Relinquishment in Western Australia, Current Practice and Future Directions, Murdoch University, Murdoch, viewed 24 July 2019, https://www.academia.edu/36167392/Mining_Tenure_Relinquishment_in_ Western_Australia_Current_Practice_and_Future_Directions

Franks, DM, Davis, R, Bebbington, AJ, Ali, SH, Kemp, D \& Scurrah, M 2014, 'Conflict translates environmental and social risk into business costs', PNAS Early Edition, vol. 111, no. 21, https://doi.org/10.1073/pnas.1405135111

International Council on Mining and Metals 2008, Planning for Integrated Mine Closure: Toolkit, London.

Lacy, H \& Bennett, K 2016, 'Updating the leading practice sustainable development (LPSD) Mine Closure Guide Australia 2015', paper presented at the Goldfields Environmental Management Group Workshop, Kalgoorlie, 20 May 2016.

Lacy, H \& Koontz, D 2002, Environment Australia, Best practice environmental management in mining - mine decommissioning, Commonwealth of Australia, Canberra.

Larance, AJ 2012, 'Mt Kembla Mine rehabilitation and memorial pathway: a case study of effective stakeholder engagement to ensure successful final land use planning and environmentally and socially sensitive project outcomes', in AB Fourie \& M Tibbett (eds), Proceedings of the Seventh International Conference on Mine Closure, Australian Centre for Geomechanics, Perth, pp. 731-746.

Lindbeck, K \& Hannan, J 1998, Landform Design for Rehabilitation - a Module in Best Practice Environmental Management in Mining, Department of Environment, Canberra.

Mackenzie, S 2016, 'Post closure funding initiatives to facilitate custodial transfer and relinquishment of mining tenure', in AB Fourie \& M Tibbett (eds), Proceedings of the 11th International Conference on Mine Closure, Australian Centre for Geomechanics, Perth, pp. 419-422.

Minerals Council Australia 1998, Mine Rehabilitation Handbook, Kingston.

Mulder, I, de Poot, H, Verwijs, C, Janssen, R \& Bijlsma, M 2006, 'An information overload study: using design methods for understanding', Proceedings of the 18th Australia Conference Computer-Human Interaction, Association for Computing Machinery, New York, pp. 245-252.

Owen, J \& Kemp, D 2018, An Industry Discussion Paper - Mine Closure and Social Performance, Centre for Social Responsibility in Mining, Sustainable Minerals Institute, University of Queensland, Brisbane.

Ropeik, D 2002, Understanding Factors of Risk Perception, Nieman Foundation for Journalism at Harvard, Cambridge, viewed 24 July 2019, https://niemanreports.org/articles/understanding-factors-of-risk-perception

Slovic, P 2001, The Perception of Risk, Earthscan, London.

Slovic, P \& Peters, E 2006, 'Risk perception and affect', Current Directions in Psychological Science, vol. 15, iss. 6, https://doi.org/10.1111/j.1467-8721.2006.00461.x

Smith, H 2012, 'Indigenous perspectives on closure and abandonment of mines and oil wells', in AB Fourie \& M Tibbett (eds), Proceedings of the Seventh International Conference on Mine Closure, Australian Centre for Geomechanics, Perth, pp. 641-649.

Solomon, F, Katz, E \& Lovel, R 2008, 'Social dimensions of mining: research, policy and practice challenges for the mineral industry in Australia', Resources Policy, vol. 33, pp. 142-149.

van der Linden, S \& Lewandowsky, S 2015, 'How to combat distrust of science, the surprising power of the psychology of consensus', Scientific American, https://www.scientificamerican.com/article/how-to-combat-distrust-of-science/

Wang, L, Awuah-Offei, K, Que, S \& Yang, W 2016, 'Eliciting drivers of community perceptions of mining projects through effective community engagement', Sustainability, vol. 8, no. 7, https://doi.org/10.3390/su8070658

Ward, S 1995, Rehabilitation and Vegetation - a module in Best Practice Environmental Management in Mining, Environmental Protection Agency, Canberra. 
